\title{
Assessment of the aerosol optical depths measured by satellite-based passive remote sensors in the Alberta oil sands region
}

\author{
Christopher E. Sioris, Chris A. McLinden, Mark W. Shephard, Vitali E. Fioletov, and Ihab Abboud \\ Environment and Climate Change Canada (ECCC), Toronto, ON, Canada \\ Correspondence to: Christopher E. Sioris (christopher.sioris@ canada.ca)
}

Received: 18 August 2016 - Discussion started: 12 October 2016

Revised: 17 January 2017 - Accepted: 20 January 2017 - Published: 9 February 2017

\begin{abstract}
Several satellite aerosol optical depth (AOD) products are assessed in terms of their data quality in the Alberta oil sands region. The instruments consist of MODIS (Moderate Resolution Imaging Spectroradiometer), POLDER (Polarization and Directionality of Earth Reflectances), MISR (Multi-angle Imaging SpectroRadiometer), and AATSR (Advanced Along-Track Scanning Radiometer). The AOD data products are examined in terms of multiplicative and additive biases determined using local Aerosol Robotic Network (AERONET) (AEROCAN) stations. Correlation with ground-based data is used to assess whether the satellitebased AODs capture day-to-day, month-to-month, and spatial variability. The ability of the satellite AOD products to capture interannual variability is assessed at Albian mine and Shell Muskeg River, two neighbouring sites in the northern mining region where a statistically significant positive trend (2002-2015) in $\mathrm{PM}_{2.5}$ mass density exists. An increasing trend of similar amplitude $\left(\sim 5 \%\right.$ year $\left.^{-1}\right)$ is observed in this northern mining region using some of the satellite AOD products.
\end{abstract}

\section{Introduction}

Fine-mode aerosols can be harmful to the respiratory system in large doses and are thus a critically important constituent with regard to air quality. For this reason, particulate matter with median aerodynamic diameter less than $2.5 \mu \mathrm{m}$ $\left(\mathrm{PM}_{2.5}\right)$ is one of the atmospheric observables used to calculate the Air Quality Health Index (AQHI) in Canada (Stieb et al., 2008). Similar indices are used in other countries (Kelly et al., 2012). Tropospheric aerosols are also a major source of uncertainty in estimating the radiative forcing of climate
(Myhre et al., 2013). Many satellite-based instruments can provide information about atmospheric aerosols in the form of aerosol optical depth (AOD), a measure of the vertically integrated extinction of the solar beam by aerosols. Measurements of AOD tend to be proportional to particulate matter mass density measured at the surface when the boundary layer aerosol concentrations are elevated (e.g. Tian and Chen, 2010).

The Alberta oil sands region (AOSR) has been under rapid industrial development during the past decade (Foote, 2012). Satellite measurements already indicate a significant increasing trend in nitrogen dioxide between 2005 and 2014 (McLinden et al., 2012, 2016). Additionally, the AOSR is being deforested as part of expanding surface mining operations. This inevitably increases levels of dust, which partly arises from transportation by trucks. Dust is one of many aerosol types of relevance in the AOSR. Other main aerosol types include organic aerosols, both natural and anthropogenic (Liggio et al., 2016), as well as ammonium sulfate.

Passive remote sensing of aerosol over land is challenging because, for a cloud-free scene, most of the nadir radiance is coming from direct reflection off the surface at visible wavelengths, not from aerosol scattering. This is particularly true for the AOSR, which consists of an irregularly shaped industrial area to the south comprised of non-vegetated (cleared) mining locations and a second area to the north where mostly surface mining is occurring, as both areas have high surface albedo in the visible. Within the AOSR, the land type changes on spatial scales smaller than the typical $10 \times 10 \mathrm{~km}$ AOD footprint of a satellite-based instrument. Considering the area surrounding the AOSR, specifically the rectangular area between 55.0 and $58.5^{\circ} \mathrm{N}$ and from 114.0 to $108.5^{\circ} \mathrm{W}$, the land is covered by evergreen needleleaf forest $(70 \%)$ 
Table 1. Spatial resolution of AOD data products from selected satellite instruments. The third column contains the wavelength at which aerosol optical depth is reported in each satellite data product. MISR and both MODIS instruments are currently operating.

\begin{tabular}{lllll}
\hline Satellite & Time period & $\begin{array}{l}\text { Wavelength } \\
(\mathrm{nm})\end{array}$ & $\begin{array}{l}\text { Spatial resolution of AOD } \\
\text { superpixel at nadir }\left(\mathrm{km}^{2}\right)\end{array}$ & $\begin{array}{l}\text { Spatial resolution of } \\
\text { radiances }\left(\mathrm{km}^{2}\right)\end{array}$ \\
\hline MISR & $2000-2015$ & 558 & $17.6 \times 17.6$ & $1.1 \times 1.1$ \\
\hline $\begin{array}{l}\text { MODIS: Terra } \\
\text { Aqua }\end{array}$ & $\begin{array}{l}2000-2015 \\
2002-2015\end{array}$ & $470,550,660$ & $10 \times 10($ also $3 \times 3)$ & $0.25 \times 0.25$ to $1 \times 1$ \\
\hline $\begin{array}{l}\text { POLDER: } 1 \\
2\end{array}$ & $1996-1997$ & 865 & $18 \times 21$ & $6 \times 7$ \\
$\begin{array}{l}\text { (PARASOL) } 3 \\
2003\end{array}$ & $2005-2013$ & & & $1 \times 1$ \\
\hline $\begin{array}{l}\text { ATSR: ATSR-2 } \\
\text { AATSR }\end{array}$ & $1995-2003$ & 550 & $10 \times 10$ & \\
\hline
\end{tabular}

and some deciduous broadleaf forest $(23 \%)$, which is typical of the boreal forest in the northern portions of Alberta and Saskatchewan.

\section{Method}

In order to study the spatiotemporal distribution of AOD in the AOSR, data from several satellite-based instruments are used. Satellite-based aerosol sensors are chosen based on a number of factors. One of the goals of the study is to examine long-term AOD trends, so preference is given to instruments with longer data records. Instruments that view a scene with multiple viewing angles were selected as the multi-angle capability is useful for disentangling the contributions to the scene reflectance by the surface and by the overlying aerosols (e.g. Bevan et al., 2012). Such instruments include Multi-angle Imaging SpectroRadiometer (MISR) (Diner et al., 1989), the Polarization and Directionality of Earth Reflectances (POLDER) series (Deschamps et al., 1994) including POLDER/PARASOL (Polarization \& Anisotropy of Reflectance for Atmospheric Sciences coupled with Observations from a Lidar), and the Along-Track Scanning Radiometer (ATSR) series (see Table 1 for the spatial resolution, temporal coverage, and wavelength at which AOD is reported for each of the satellites). In addition, MODIS (Moderate-resolution Imaging Spectroradiometer) is chosen partly because it has a long-wavelength channel $(2.1 \mu \mathrm{m})$ that allows the surface reflectance to be accurately determined over vegetation without contamination from fine-mode aerosols (e.g. particles with radii of $<0.2 \mu \mathrm{m})$ by virtue of the correlation between visible and $2.1 \mu \mathrm{m}$ surface reflectance for vegetation (e.g. Kaufman et al., 2002; Li et al., 2005). MODIS Aqua collection 6 data are used (see Sect. 5 for providers and version numbers of other satellite data products). For MODIS, there are two AOD retrieval algorithms yielding the Dark Target (DT) (Levy et al., 2013) and the Deep Blue (DB) (Hsu et al., 2013) products. Specifically, the Corrected_Optical_Depth_Land $(550 \mathrm{~nm})$ and the Deep_Blue_Aerosol_Optical_Depth_550_Land data sets were used, and confidence for both data sets was extracted from the Quality_Assurance_Land data set. The Dark Target algorithm exploits the fact that, for dark surfaces, aerosols tend to brighten the scene. For highly reflective surfaces such as snow in the visible spectral region, AOD cannot be retrieved using either the DT or DB approach. The MODIS Aqua DT product is also processed at $3 \mathrm{~km}$ spatial resolution in addition to the standard $10 \mathrm{~km}$ resolution available for both MODIS products (Levy et al., 2013). Each MODIS AOD measurement is assigned a confidence value. Confidence values of 1 and 0 indicate marginal and no confidence, respectively, while values of 2 and 3 represent good and ideal confidence (Levy et al., 2013). For MODIS Aqua collection 6 , data with confidence $\geq 1$ are retained for validation. The theoretical basis of the MISR aerosol retrieval algorithm is given by Diner et al. (2008). The aerosol retrieval for the Advanced Along-Track Scanning Radiometer (AATSR) is described by Bevan et al. (2012) and references therein. Deuzé et al. (2001) detail the approach used to retrieve aerosol information from POLDER observations over land.

MODIS Terra is not considered since it is highly similar to MODIS Aqua, but, for collection 6, the former is less reliable for trend studies in spite of improvements relative to collection 5 (Levy et al., 2015). The MODIS-based Multiangle Implementation of Atmospheric Correction (MAIAC) (Lyapustin et al., 2011) product is not currently available in the AOSR (van Donkelaar et al., 2016). VIIRS (Visible Infrared Imaging Radiometer Suite) (Hillger et al., 2013) is not considered in this study because of its shorter data record relative to the MODIS sensors. Active remote-sensing instruments are not considered because of the long revisit time and poor spatial coverage of the relatively small AOSR. The focus in this paper is primarily on the different aerosol sensors, rather than the different retrieval algorithms applied to the same satellite data (e.g. Popp et al., 2016), with the exception 
of the widely used Deep Blue and Dark Target algorithms for MODIS.

For validation of satellite-based AOD data, the Aerosol Robotic Network (AERONET; Holben et al., 1998) is the ideal choice since the same quantity is measured by this ground-based network of direct-sun multiband photometers, and the $\sim 3$ min typical sampling interval generally ensures a good temporal coincidence during clear-sky conditions. Quality-controlled AERONET data (Level 2, version 2) are used (http://aeronet.gsfc.nasa.gov). Cimel (French manufacturer) CE318 sensors used by AERONET measure at several wavelength; some of them (e.g. 500 and $870 \mathrm{~nm}$ ) are close to the wavelengths at which the selected satellite instruments report AOD (e.g. 470, 550, and $865 \mathrm{~nm}$ ). There are two AERONET sites in the oil sands region: Fort McMurray $\left(56.752^{\circ} \mathrm{N}, 111.476^{\circ} \mathrm{W}\right)$ and Fort McKay $\left(57.184^{\circ} \mathrm{N}, 111.64^{\circ} \mathrm{W}\right)$. Measurements at Fort McMurray started in 2005. The Fort McKay site has only been in operation since August 2013, meaning that there is no temporal overlap with AATSR and only seven coincidences with POLDER/PARASOL using coincidence criteria of $\pm 12 \mathrm{~min}$ and $10 \mathrm{~km}$. The spatial coincidence criterion corresponds to the smallest AOD footprints of the selected data sets (Table 1). A larger spatial coincidence criterion is not considered since, as shown below, strong spatial gradients in AOD exist in this aerosol source region. Furthermore, as mentioned in Sect. 1, the surface type also changes on such spatial scales. The temporal coincidence criterion was set to limit the number of independent AERONET measurements used in the statistical analysis. There can be multiple AERONET observations that are temporally coincident with a satellite observation, and there can be up to four spatial coincident satellite AODs during a satellite overpass of an AERONET site. All of these coincidences are treated as independent data points in the validation and correlation analyses. In order to properly validate satellite AOD bias, AERONET $500 \mathrm{~nm}$ AODs are interpolated to the satellite AOD wavelengths (see Table 1) using the coincident AERONET Ångström exponent derived from 440 and $675 \mathrm{~nm}$ measurements, except for POLDER/PARASOL, for which no scaling of the AERONET AOD was applied.

Since individual AERONET and satellite AODs are not normally distributed, we use linear least squares weighted by Huber's function to determine the slope and offset since this is a robust regression method that does not completely disregard highly deviating points (Bergström and Edlund, 2014). The slope and offset values determined using $\mathrm{Hu}$ ber's weighting function are encompassed by the values obtained with seven alternative weighting functions. Similarly, due the non-normal distribution of the individual AOD data, Spearman's rank correlation coefficient $\left(r_{\mathrm{s}}\right)$ is chosen to study the site-specific AOD correlation based on individual AERONET-satellite coincidences.

The ability of each satellite-based sensor to capture the AOD seasonality in snow-free months is determined at Fort
McMurray using Pearson's correlation of monthly averaged AODs (using all overlapping years) with AERONET. A minimum of 20 coincident data points per calendar month must be available for that month to be included in the correlation.

In order to assess the ability of the satellite data to capture the spatial variability in this region, the hourly in situ surface-level $\mathrm{PM}_{2.5}$ observations from the 10 NAPS (National Air Pollution Surveillance) stations (Table 2) are used. Demerjian (2000) provided a review of the NAPS network, but since 2011 this network has undergone a gradual shift in the continuous monitoring of $\mathrm{PM}_{2.5}$ mass density from tapered element oscillating microbalances (TEOMs) to the SHARP (Synchronized Hybrid Ambient Real-time Particulate) monitoring system. The latter is a hybrid system, consisting of a nephelometer and a beta attenuation monitor (Hsu et al., 2016). The spatial correlation between median satellite AODs and NAPS $\mathrm{PM}_{2.5}$ mass densities is determined using coincident data. The use of medians rather than means reduces the sensitivity to outliers from forest fires. The same $10 \mathrm{~km}$ spatial coincidence criterion is used, but temporal coincidence limit is extended to $\pm 1 \mathrm{~h}$ to match the temporal resolution of the selected NAPS data sets.

Similar to the spatial and seasonal variability, the ability of the satellite instruments to capture interannual variability can be assessed by correlating yearly satellite-based AODs averaged over all coincidences with NAPS $\mathrm{PM}_{2.5}$ measurements during the overlap period. Twenty coincidences in a calendar year are required for the year to be included in the correlation calculation. As an example, for MISR, 14 sufficiently sampled years (2002-2015) are used in the correlation with NAPS data at Millennium mine.

For temporal trends, an ordinary least-squares simple linear regression is performed on relative anomalies derived from bias-corrected annual average and median AODs. The bias correction involves subtracting the AOD offset obtained through the validation with coincident Fort McMurray AERONET data. The mean of the yearly averages or medians is used to compute the relative anomalies. Similarly, for $\mathrm{PM}_{2.5}$, the annual average of daily average values are used since the $\mathrm{PM}_{2.5}$ auto-correlation timescale is on the order of $6.5 \mathrm{~h}$, based on analysis of Albian mine $\mathrm{PM}_{2.5}$ data from 2002. The extra step of daily averaging prior to annual averaging yields more conservative annual standard error (s. e.) estimates. Partial years at the start and the end of a data record are removed. Trend periods are given below for each sensor. The area over which the satellite-based AOD trend maps are calculated is $0.1^{\circ} \times 0.1^{\circ}$ by default. This default setting is used to determine the AOD trend for both MODIS Aqua $10 \mathrm{~km}$ products (2003-2015). The trend domain considered in this work spans $56-58^{\circ} \mathrm{N}$ and $111-$ $112^{\circ} \mathrm{W}$. For sensors with poorer spatial coverage (MISR, AATSR, POLDER/PARASOL), the spatial binning is expanded in latitudinal and longitudinal increments of $0.1^{\circ}$ until there are $\geq 20$ observations in each calendar year within at least one grid cell in the domain. The trend maps are ulti- 
Table 2. Selected NAPS $\mathrm{PM}_{2.5}$ sites and time span of available data (inclusive).

\begin{tabular}{lrrr}
\hline Station name & Lat $\left({ }^{\circ} \mathrm{N}\right)$ & Lon $\left({ }^{\circ} \mathrm{W}\right)$ & Time span \\
\hline Anzac & 56.4493 & -111.0372 & $2006-2015$ \\
Fort McMurray Athabasca Valley & 56.7328 & -111.39 & $1997-2015$ \\
Fort McMurray Patricia McInnes & 56.7522 & -111.476 & $1999-2015$ \\
Millennium mine & 56.97 & -111.4 & $2001-2015$ \\
Syncrude Upgrader Expansion 1 & 57.1492 & -111.642 & $2002-2015$ \\
Fort McKay & 57.1894 & -111.641 & $1997-2015$ \\
Wapasu & 57.2383 & -110.9028 & $2013-2015$ \\
Shell Muskeg River & 57.2491 & -111.508567 & $2009-2015$ \\
Albian mine & 57.2808 & -111.526 & $2001-2009$ \\
Canadian Natural Resources Ltd. Horizon & 57.3037 & -111.739617 & $2008-2015$ \\
\hline
\end{tabular}

mately generated at $0.3^{\circ} \times 0.3^{\circ}$ for AATSR (2003-2011) and MISR (2000-2015), whereas a $0.4^{\circ} \times 0.4^{\circ}$ area is required for POLDER/PARASOL (2005-2013). Outlying individual data points ( $>4$ standard deviations above the climatological average in the domain) are recursively filtered mainly to reduce the influence of forest fires on trends. The same filtering is applied to the $\mathrm{PM}_{2.5}$ data sets. Interannual consistency in the month-to-month sampling is checked for any location with a positive satellite AOD trend significant at the $95 \%$ confidence interval by calculating the average day of the year for each calendar year. Such temporal sampling anomalies would occur for MISR AOD data at some locations if a $0.1^{\circ} \times 0.1^{\circ}$ grid were used, for example. The Albian mine (2001-2008) and Shell Muskeg River (2009-2015) forestfire-filtered $\mathrm{PM}_{2.5}$ data sets were merged for trend analysis since the sensor was relocated from the former to the latter site in January 2009 , and these sites are separated by $<5 \mathrm{~km}$.

\section{Results}

First, the general spatial distribution of AOD is illustrated for some of the aforementioned data sets. In Fig. 1, the climatological average POLDER AOD on a $0.1^{\circ} \times 0.1^{\circ}$ grid is shown. This is the default grid used for climatological maps of all satellite AOD data sets. The POLDER sample size per grid cell is 90 to 170 in the AOSR over the discontinuous period from 1996 to 2013 (see Table 1). There is a clear hotspot in $865 \mathrm{~nm}$ AOD in the AOSR region, roughly double the surrounding background values. Note that for POLDER and MISR there are expected voids in their spatial coverage (Fig. 1) due to the spatial sampling of these instruments, whereas MODIS and AATSR footprints can be centred on any geolocation within the AOSR.

The AOD hotspot in the AOSR seen by POLDER is less obvious with MISR (Fig. 1). This is consistent with the relatively poorer ability of MISR to capture spatial variability based on spatial correlations of median AOD and $\mathrm{PM}_{2.5}$ mass density over the $\sim 10$ available sites (Table 3 ). While the spatial correlation analysis relies on temporally coincident data,
Table 3. Spatial correlation between $\mathrm{PM}_{2.5}$ mass density and AOD using medians of coincident data at 10 sites in the AOSR. Wapasu has insufficient or no temporal overlap with POLDER/PARASOL and AATSR. Syncrude UE1 is not spatially coincident with any of the POLDER locations given the $10 \mathrm{~km}$ criterion (see Sect. 2).

\begin{tabular}{lrr}
\hline AOD product & $R$ & $N$ \\
\hline POLDER/PARASOL 865 nm & 0.64 & 8 \\
AATSR 550 nm & 0.73 & 9 \\
MISR 558 nm & 0.20 & 10 \\
MODIS Aqua DT 550 nm & 0.23 & 10 \\
MODIS Aqua DB 550 nm & 0.57 & 10 \\
\hline
\end{tabular}

the less obvious AOD hotspot for MISR in Fig. 1 is also partly due to the spatiotemporal sampling by this instrument. Some locations are only sampled during a short period of the year, and thus the seasonal cycle of AOD is aliased into the MISR spatial distribution. Table 4 provides the number of coincidences for each satellite with both the Fort McMurray and Fort McKay AERONET observations to provide a sense of how the coincident sample sizes vary as a function of the satellite AOD data product.

The climatological AOD maps for the MODIS Aqua collection 6DT and DB products (2002-2014) are also shown in Fig. 1; however there is a major issue with the confidence as shown in Fig. 2. Near the Syncrude facility at Mildred Lake $\left(57.05^{\circ} \mathrm{N}, 111.6^{\circ} \mathrm{W}\right)$, the confidence approaches 0 in both MODIS products in the two adjacent $0.1^{\circ} \times 0.1^{\circ}$ cells (Fig. 2). In the western cell, the inadequate confidence in MODIS Aqua collection 6DT data is due to failure of the AOD retrieval algorithm due to the $2.1 \mu \mathrm{m}$ reflectance exceeding the allowed upper limit of 0.35 . This is a fundamental limitation of the Dark Target retrieval strategy (see Sect. 2). In the adjacent eastern cell, the low confidence stems from the low number of $0.5 \times 0.5 \mathrm{~km}^{2}$ pixels (see Table 1) used in the AOD retrieval. The number of pixels used in the AOD retrieval is reduced by the inland water mask (Carroll et al., 2017) and the high $2.1 \mu \mathrm{m}$ reflectance (>0.35), and also by cloud masking and an independent test for optically 

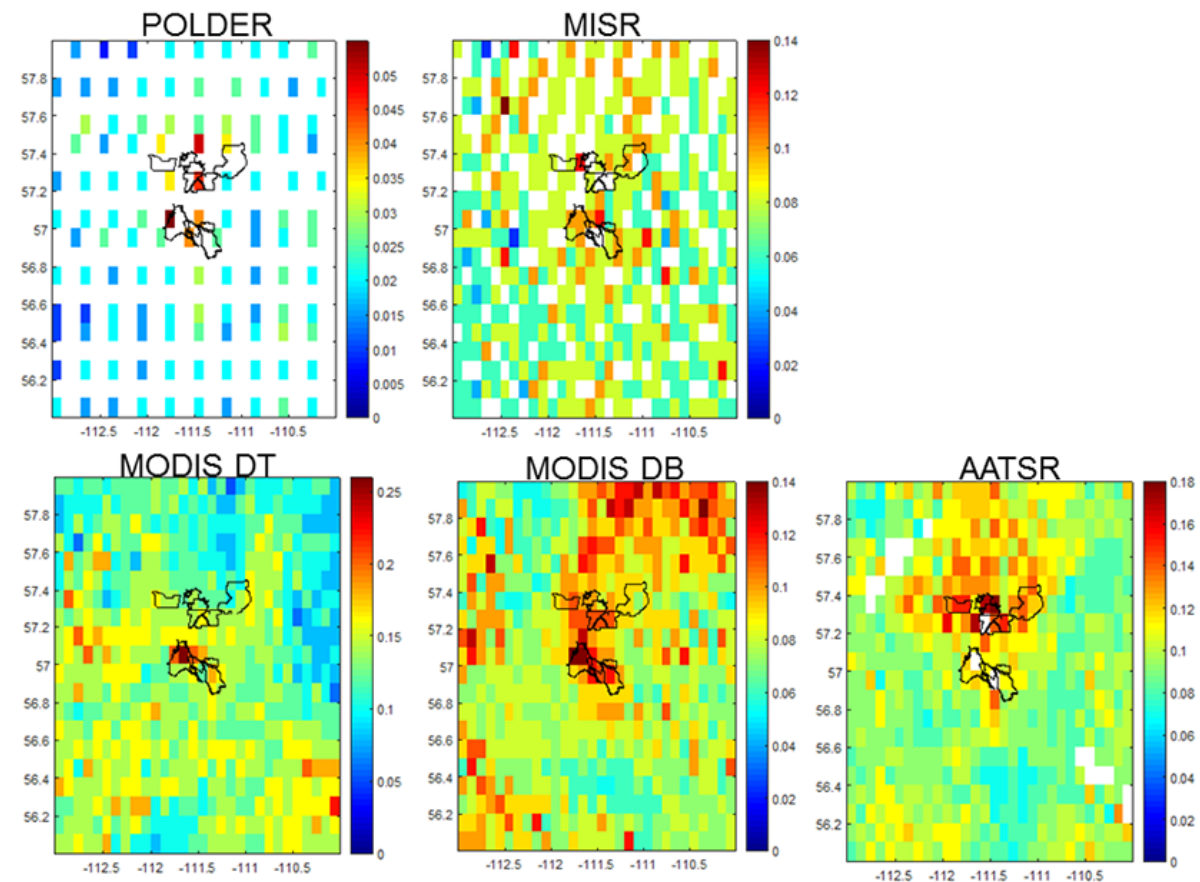

Figure 1. Climatological average AOD maps on a $0.1^{\circ} \times 0.1^{\circ}$ latitude-longitude grid. Top left: POLDER $865 \mathrm{~nm}$ (1996-2013). Note the gaps in time between the different members of the POLDER series in Table 1. Top right: MISR $558 \mathrm{~nm}$ (2000-2015). Bottom left: MODIS Aqua DT using only confidence of 3 (2002-2015). Bottom centre: MODIS Aqua DB using only confidences of 2-3 (2002-2015) following Sayer et al. (2013). Bottom right: AATSR $550 \mathrm{~nm}$ (2002-2012). Typical $N$ is $\sim 65$ for AATSR (see below), and white areas indicate $N<20$. Black lines trace out the three surface mining areas in this and subsequent figures. Average coincident AERONET AOD at Fort McMurray is superimposed as a diamond with a black outline. In each panel, the AOD ranges from 0 to the greater of the maximum climatological mean satellite AOD or the Fort McMurray AERONET mean AOD, except for MISR, for which the AOD range is capped at 0.14 to not emphasize the anomalously high AOD at Moose Lake $\left(57.6^{\circ} \mathrm{N}, 112.5^{\circ} \mathrm{W}\right)$.

thicker cirrus, diagnosed using the $1.38 \mu \mathrm{m}$ channel (Levy et al., 2013; Hubanks, 2015). The high reflectance in the near infrared affecting the western cell and possibly the eastern cell is typical of desert or sandy loam. The higher spatial resolution of the MODIS-Aqua $3 \mathrm{~km}$ DT data clarifies the importance of this issue: key areas in the AOSR are simply not monitored with confidence by the current MODIS Aqua DT product. For example, there are $0.01^{\circ} \times 0.01^{\circ}$ areas with no AOD measurements of the highest confidence in 12 years, whereas surrounding, equal areas have tens of observations. The lack of confidence is not unique to the AOSR. Low confidence is also observed in urban areas within the province (e.g. Calgary, not shown). The low confidence in the MODIS DB product is due to the spatial heterogeneity of the surface between vegetated and non-vegetated area, which leads to pixels falsely identified as cloudy (N. C. Hsu, NASA, personal communication, 2015). Li et al. (2009) identified the need for improved AOD measurements using the DB algorithm over transitional land covers.

A similar issue exists for AATSR (Fig. 3) and ATSR-2 (not shown), which both have an exceedingly small number of successful retrievals in a $0.1^{\circ} \times 0.1^{\circ}$ area containing the Mildred Lake Syncrude facility (e.g. $N<10$ ) during their respective missions (Table 1). Similarly to MODIS, this is probably caused by falsely identifying bright patches in otherwise vegetated scenes as clouds (P. North, Swansea University, personal communication, 2016). Cloud fraction for successful AOD retrievals tends to be as high as 0.18 within the oil sands region, including the northern mining region, yet drops to 0.02 in the surrounding region (Fig. 3). Note that cloudy $1 \times 1 \mathrm{~km}^{2}$ pixels are not used during the AATSR AOD retrieval. The spatial correlation coefficient between sample size and cloud fraction as illustrated in Fig. 3 is -0.73 , indicating that the spatial variation in AATSR sample size is mostly related to cloud flagging. Neither POLDER nor MISR show a sampling void in the AOSR. Table 1 shows that these two sensor types have coarser AOD spatial resolution by a factor of 3-4 than MODIS, ATSR-2, and AATSR. Note that some of the $\mathrm{PM}_{2.5}$ sites are located in the periphery of the industrial and mining areas, and thus spatial coincidences exist for MODIS and AATSR in spite of the aforementioned issues, given the $10 \mathrm{~km}$ coincidence criterion.

In terms of the validation using AERONET data (Table 4), MISR has a multiplicative bias (i.e. slope significantly less than unity), which is similar at both sites in the AOSR. The slope is of a similar value to the slope found in previous stud- 

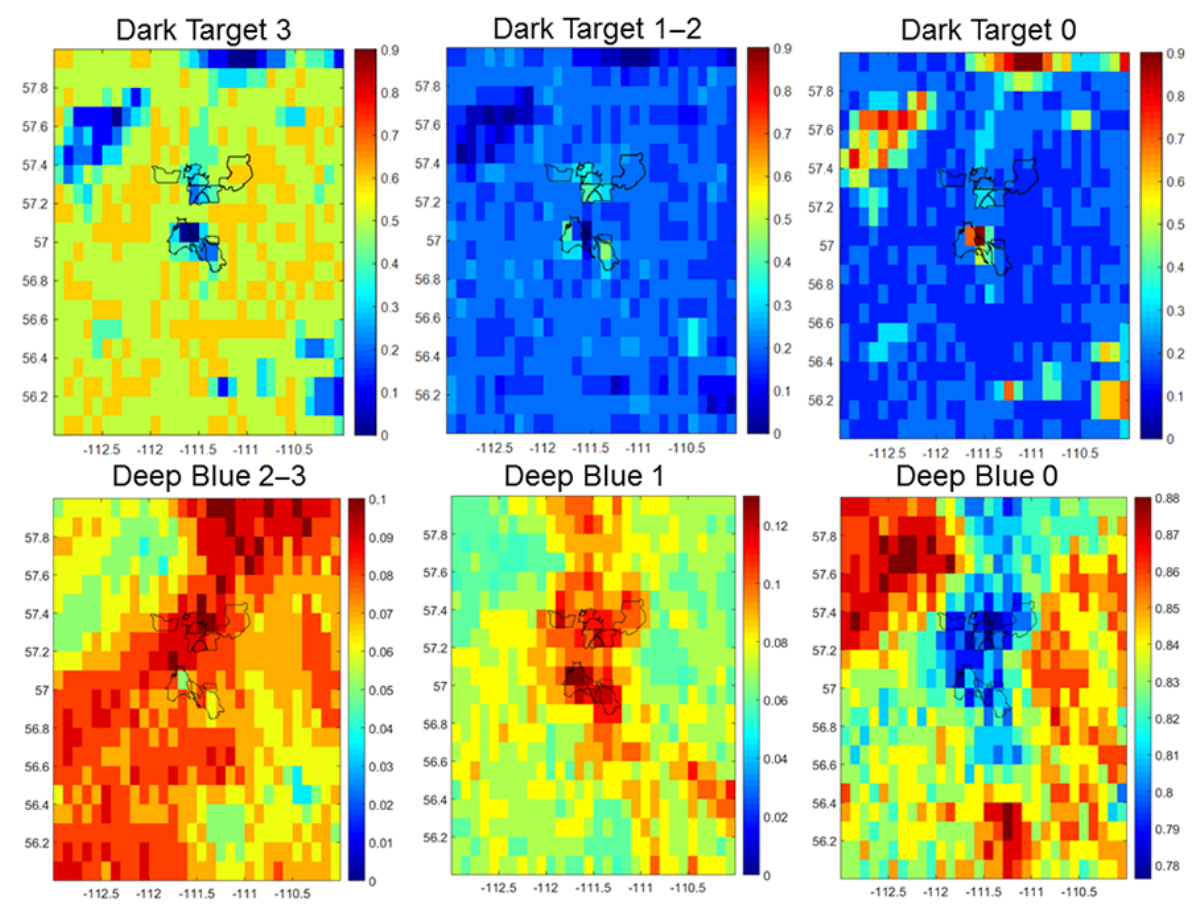

Figure 2. Maps of fraction of pixels with a specific confidence (2002-2015) for MODIS Aqua DT (top) and DB (bottom) AODs. Lower confidence is expected over Moose Lake and the Richardson sand dunes $\left(58.0^{\circ} \mathrm{N}, 111.0^{\circ} \mathrm{W}\right)$. MODIS DB only reports a fill value when confidence is 0 in contrast to MODIS DT; thus the bottom right plot accounts for fill values, whereas the top right plot (for MODIS DT) does not.
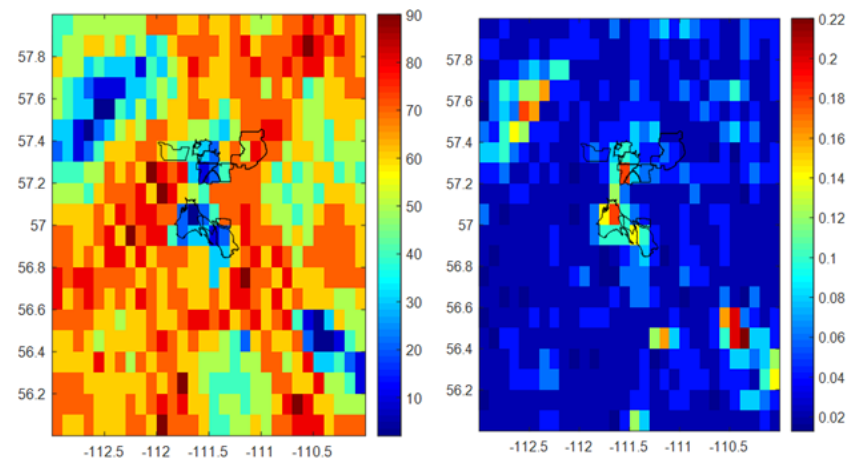

Figure 3. Map of sample size (left) and average cloud fraction within AOD superpixels when the AOD retrieval is successful (right), compiled from the entire AATSR data record. Smaller sample sizes are expected over Moose Lake and Gordon Lake $\left(56.5^{\circ} \mathrm{N}\right.$, $\left.110.5^{\circ} \mathrm{W}\right)$.

ies for inland (Liu et al., 2004), dusty (Kahn et al., 2005), and urban environments (Jiang et al., 2007). MODIS DB tends to yield more data than the DT product, but the correlation is lower with AERONET on individual coincidences and in terms of the seasonal variation. At the Fort McMurray AERONET sites, the MODIS products behave oppositely in terms of multiplicative and additive biases (discussed in
Sect. 4). AATSR and POLDER/PARASOL have no major validation shortcomings.

\section{Trends}

Before considering trends in the AOSR, it is useful to look at whether the different satellite data products capture the AOD interannual variability at Fort McMurray, where a sufficiently long record (2005-2015) of 500 nm AOD exists. All of the products capture the interannual variability of the annual mean AOD observed by AERONET at Fort McMurray (Table 5). Correlation coefficients for forest-fire-filtered annual means tend to be only slightly lower.

In general, very few of the 200 grid cells in the trend domain $\left(56-58^{\circ} \mathrm{N}, 111-112^{\circ} \mathrm{W}\right)$ indicate a statistically significant $(2$ s.e.) positive trend that is consistent from one satellite to the next. In fact, for all points in this domain, MODIS Aqua DT (2003-2015), AATSR, and ATSR-2 (1996-2002, $0.3^{\circ} \times 0.3^{\circ}$ ) do not show a significant AOD trend. Similarly, POLDER/PARASOL only shows a significant positive trend in three adjacent grid points at $57.3^{\circ} \mathrm{N}$ between 111.3 and $111.5^{\circ} \mathrm{W}$ (see Fig. 4), and MISR also finds a significant positive trend at only two locations in the domain. Finally, MODIS Aqua DB has two points, with the largest and most significant positive AOD trend being in the region of the Muskeg River mine at $57.25^{\circ} \mathrm{N}, 111.25^{\circ} \mathrm{W}$ (Fig. 4). In fact, two satellite data products, namely POLDER/PARASOL and 
Table 4. Statistical comparison of coincident AODs observed by satellite-based sensors and AERONET Cimel sun photometers. For each satellite AOD product, the upper row is for Fort McMurray and the lower row is for Fort McKay. The Cimel 500 nm AOD, scaled to the satellite AOD wavelength (see Sect. 2), is used for comparison with all satellite sensors except POLDER/PARASOL, for which the Cimel $870 \mathrm{~nm}$ AOD is more appropriate (see Table 1). The number of MISR-Fort McKay coincidences is insufficient to assess the month-to-month variability.

\begin{tabular}{lllllll}
\hline Sensor & $r_{\mathrm{s}}$ & Slope & Offset & $\begin{array}{l}\text { Seasonal } \\
r\end{array}$ & $\begin{array}{l}\text { Month } \\
\text { range }\end{array}$ & $N$ \\
\hline Aqua DB v6 & 0.793 & 0.867 & 0.0233 & 0.84 & $4-10$ & $\begin{array}{l}5508 \\
426\end{array}$ \\
& 0.686 & 1.013 & 0.0036 & 0.84 & $4-10$ & 626 \\
\hline Aqua DT v6 & 0.875 & 1.210 & -0.0117 & 0.99 & $4-10$ & 4197 \\
& 0.806 & 1.088 & & 0.95 & $5-9$ & 431 \\
& & & -0.0223 & & & \\
\hline PARASOL & 0.867 & 0.831 & -0.018 & 0.89 & $5-10$ & 414 \\
& - & - & - & - & - & - \\
\hline AATSR & 0.888 & 0.862 & 0.0253 & 0.96 & $5-10$ & 560 \\
& - & - & - & - & - & - \\
\hline MISR & 0.862 & 0.731 & 0.0219 & 0.88 & $3-9$ & $\begin{array}{l}337 \\
-\end{array}$ \\
\hline
\end{tabular}

Table 5. Correlation of annual mean AODs with Fort McMurray AERONET AODs during the respective overlap periods of the various satellite AOD products. In the rightmost column, the contribution of large forest fires has been removed from AERONET data and satellite data sets using +4 standard deviations $(\sigma)$ as a cutoff.

\begin{tabular}{lrr}
\hline & $\begin{array}{r}\text { Including }+4 \sigma \\
\text { outliers }\end{array}$ & $\begin{array}{r}\text { Excluding }+4 \sigma \\
\text { outliers }\end{array}$ \\
\hline POLDER/PARASOL & 0.995 & 0.81 \\
MISR & 0.91 & 0.94 \\
AATSR & 0.98 & 0.92 \\
MODIS DT & 0.98 & 0.94 \\
MODIS DB & 0.91 & 0.86 \\
\hline
\end{tabular}

MODIS Aqua DB, exhibit a statistically significant positive trend in this mining area. Although not statistically different from zero, the AOD trend in both AATSR and MISR data is positive in the area of the positive POLDER/PARASOL trend (Fig. 4), whereas MODIS DT tends to show an insignificant negative trend.

Changes to the surface may be at the root of the increasing AOD trend in this area, either by clearing of vegetation leading to higher concentrations of dust or by biasing the AOD retrieval. Trends in surface albedo were determined from the combined MODIS Terra/Aqua MCD43C3 albedo data product at four wavelengths relevant to the MODIS or POLDER AOD retrievals: 470, 645, 860, and $2130 \mathrm{~nm}$ (see Appendix A). For all four wavelengths, neither the largest nor the most significant trends in surface reflectivity occur at $57.25^{\circ} \mathrm{N}, 111.25^{\circ} \mathrm{W}$ (not shown), where the largest and most significant MODIS DB AOD trend occurs and also within the larger area of the spatially coherent POLDER/PARASOL AOD trend.

Since aerosol optical depth histograms indicate a skewed distribution, it is useful to verify trends using annual medians. A significant positive trend of $(4.1 \pm 1.1) \%$ year $^{-1}( \pm 1$ standard error) (Figs. 5-6) and (5.7 \pm 1.6$) \%$ year $^{-1}$ is detected in the Albian mine-Shell Muskeg River merged annual average and median $\mathrm{PM}_{2.5}$ mass densities (2002-2015), respectively. When the merged $\mathrm{PM}_{2.5}$ data set is limited to the warm season (April-October) to mimic the temporal coverage of the satellite data (Table 4), the relative trend using annual averages is $(4.6 \pm 1.2) \%$ year $^{-1}$, which is not a significant change from the trend using year-round data (Fig. 6). A consistent trend of $(4.8 \pm 2.1) \%$ year $^{-1}$ is found in annually averaged $\mathrm{PM}_{2.5}$ at Albian mine (2002-2008) alone, and the trend there during the warm season is $(4.3 \pm 1.1) \%$ year $^{-1}$, also statistically significant and not different from the yearround trend. Furthermore, there is no indication of a discontinuity between 2008 and 2009, when the monitoring site was relocated. The relative trend in $\mathrm{PM}_{2.5}$ at the surface is in quantitative agreement with the relative trends derived from MODIS Aqua Deep Blue and POLDER/PARASOL annually averaged AOD data over similar, yet shorter periods. For both MODIS Aqua Deep Blue and POLDER/PARASOL, trends using annual medians agree with trends determined using annual averages within their respective standard errors (1 s. e.).

Contrary to the localized, significant AOD trend in satellite data records in the eastern portion of the Muskeg River region, a statistically significant trend is found at two other ground-based stations within the AOSR for the period 20022014, namely Syncrude Upgrader Expansion 1 (UE1) and Millennium mine (Fig. 6). The largest trend occurs at Mil- 


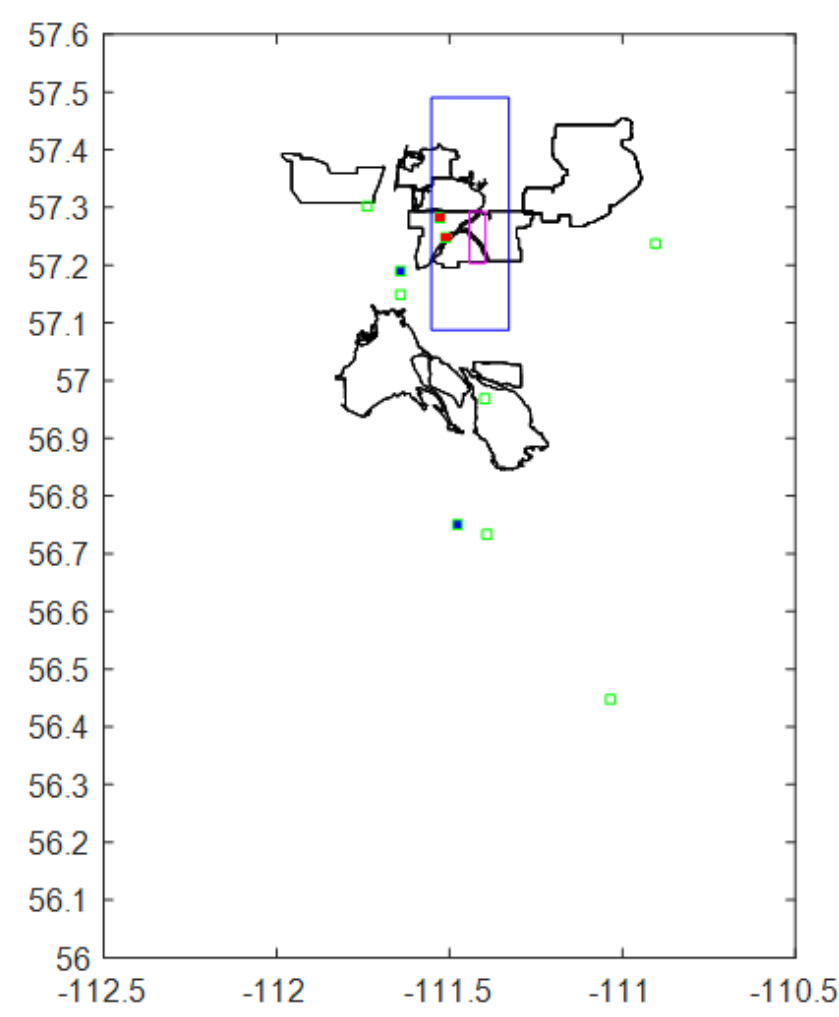

Figure 4. Areas with a significant positive trend in AOD in the POLDER/PARASOL and MODIS Aqua DB data records. The area over which the AOD time series is determined for MODIS Aqua DB $\left(0.1 \times 0.1^{\circ}\right)$ and POLDER/PARASOL $\left(0.4 \times 0.4^{\circ}\right)$ is outlined in pink and blue, respectively. Locations of 10 NAPS PM 2.5 monitoring sites are also shown as small green squares. The central one of three adjacent (overlapping) grid cells at constant latitude is plotted for POLDER/PARASOL (see Sect. 3 for details). The grid cell with the largest trend in the domain is plotted for MODIS Aqua DB (see Sect. 3 for details). Note that the Albian mine site $\left(57.2808^{\circ} \mathrm{N}\right.$, $111.526^{\circ} \mathrm{W}$ ) was replaced by the nearby Shell Muskeg River site $\left(57.2491^{\circ} \mathrm{N}, 111.509^{\circ} \mathrm{W}\right.$ ) in 2009 (both station symbols are filled in red). The two AERONET instruments are co-located with NAPS monitors, and the markers for those sites are filled in blue.

lennium mine, the closest NAPS station to the southeast of the Shell Muskeg River region (see Table 2 and Fig. 4 for location). The trend is insignificant using either annual mean or median $\mathrm{PM}_{2.5}$ data at Canadian Natural Resources Limited (CNRL) Horizon and Anzac where data records are shorter, while the trend at Wapasu (2013-2015) was not evaluated. The $\mathrm{PM}_{2.5}$ trends at the remaining sites in the AOSR, namely two sites at Fort McMurray and one at Fort McKay, are discussed below. Note that POLDER/PARASOL does not measure at Syncrude UE1 (see Table 3) and that there is insufficient sampling at Millennium mine over an area of $0.4^{\circ} \times 0.4^{\circ}$ in each of the years (2005-2013) for trend analysis. For POLDER/PARASOL, the trend, while mostly insignificant in the AOSR, is always positive. For AATSR, the AOSR has regions of statistically insignificant negative and

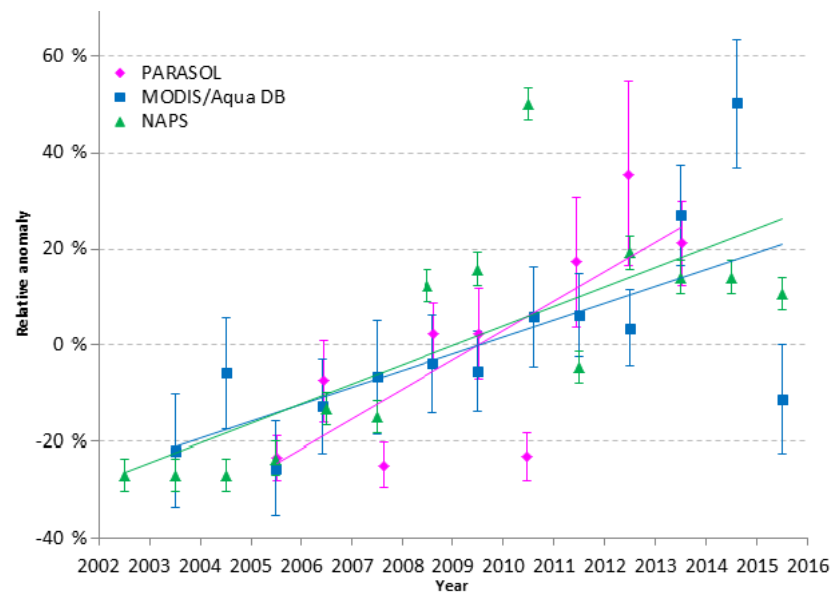

Figure 5. Relative anomalies of annual mean $\mathrm{PM}_{2.5}$ mass density for the merged Albian mine and Shell Muskeg River data set, along with relative anomalies of bias-corrected annual mean AODs for POLDER/PARASOL and MODIS Aqua DB (see Sect. 3 for details and Fig. 4 for satellite trend areas). Each satellite time series is plotted at the average decimal time for each calendar year. Trend lines are fitted to each time series using a matching colour. Vertical error bars indicate \pm 1 relative standard error of the annual mean. There are, on average, 33 and 50 observations per year for POLDER/PARASOL and MODIS Aqua DB, respectively.

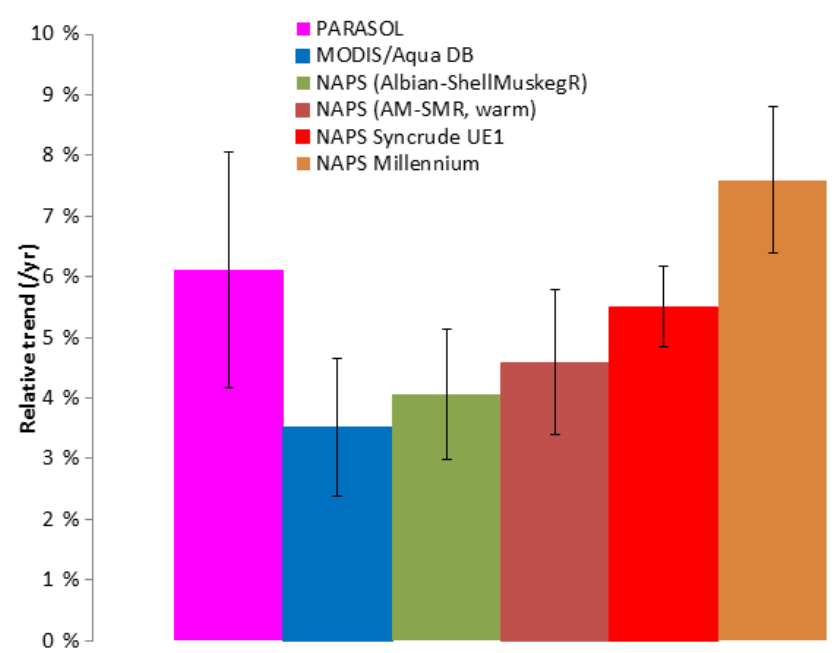

Figure 6. Relative trend in annually averaged $\mathrm{PM}_{2.5}$ mass density calculated using NAPS $\mathrm{PM}_{2.5}$ data for three locations, namely the merged Albian mine and Shell Muskeg River data set (2002-2015), Millennium mine (2002-2014) and Syncrude UE1 (2003-2014), or in satellite AODs in the vicinity of Shell's Albian and Muskeg River mines (see Fig. 4 and Sect. 3). The trend is also determined for the NAPS PM 2.5 merged Albian mine-Shell Muskeg River (AMSMR) data set, limited to the warm season (April to October). Trend uncertainty is indicated with a vertical bar ( \pm 1 s. e.). 
positive trends. For MISR, the trend is positive in $56 \%$ of the trend domain and even more so $(83 \%)$ in the northern half of the domain $\left(57-58^{\circ} \mathrm{N}\right)$. For MODIS DB and DT, some of the AOSR is not sufficiently sampled with high confidence (see Sect. 2), but where confidence is $\geq 1$, the trend tends to be negative in 69 and $77 \%$ of this area, respectively. The calibration of the MODIS reflective solar bands is achieved by calibration with the solar diffuser. Some negative drift in AOD (Levy et al., 2015) is expected for MODIS Aqua similar to its Terra counterpart (see Sect. 2) as the designs of the solar diffuser and its stability monitor are nearly identical in the two MODIS sensors (Wu et al., 2013). Li et al. (2016) found a small positive trend in AOD over Athabasca (56$\left.58^{\circ} \mathrm{N}, 110-113^{\circ} \mathrm{W}\right)$ using MODIS Aqua DB data (20042015), insignificant at the 2 s. e. level. Bari and Kindzierski (2016) found no indications of a positive trend in $\mathrm{PM}_{2.5}$ at Fort McKay and the Fort McMurray Athabasca Valley site, using a longer period (1998-2014), although, as shown in Fig. 2 of Bari and Kindzierski (2016) for Fort McKay, there is an abrupt decrease in $\mathrm{PM}_{2.5}$ mass densities between 2001 and 2002 that has a profound effect on the trend and its uncertainty. This discontinuity is observed at all sites in the AOSR that extend back to 2001. An earlier study by the same authors (2015) also indicated no trend between 1998 and 2012 at the same sites and at the Fort McMurray Patricia MacInnes site as well.

\section{Discussion and conclusions}

In this section, the advantages and limitations of the various data products are summarized. As shown in Table 4, all of the satellite sensors capture the temporal variability in AOD over Fort McMurray, based on correlations with AERONET, in spite of the low AODs there (e.g. Fig. 1). This temporal variability is largely driven by day-to-day variability as forest fires lead to episodes with large AODs (>3) in summer months.

The two MODIS AOD data products (Deep Blue and Dark Target) have low confidence in the AOSR partly due to issues relating to elevated surface reflectivity in the vicinity of the Mildred Lake Syncrude facility. However, the MODIS DT product is the best at capturing temporal variability in terms of the correlation with individual AERONET AODs at Fort McMurray and in terms of capturing the month-to-month variability. Stronger short-term correlation with AERONET AODs reflects the superior spatial resolution of the MODIS radiances (Table 1), which is useful for resolving and filtering small clouds and localized areas of high surface reflectively. Focussing on Fort McMurray, where there is a longer AERONET data record than at Fort McKay, MODIS DT has a slope greater than unity, in contrast to MODIS DB (Table 4). The same pattern of high and low slope values for the MODIS Aqua DT and DB (collection 6) products, respectively, was found over two sites in Pakistan, namely La- hore and Karachi, by Bilal et al. (2016) and during non-fire summertime periods over semi-arid Nevada and California as shown in Table 4 of the work of Loría-Salazar et al. (2016). A high slope may be related to the use of the $2.1 \mu \mathrm{m}$ channel to determine the reflectivity in the visible over non-vegetated surfaces as suggested by Bilal et al. (2016). Highly biased AODs result because the surface reflectance in the visible assumed by the retrieval algorithm is less than the actual value as the relationship between the visible and $2.1 \mu \mathrm{m}$ was developed for vegetated land for which a stronger spectral variation exists than for barren land. Li et al. (2005) have shown that the spectral reflectance relationship is much different even for dry vegetation than green vegetation. Note that high day-to-day variability can be captured in spite of biases in assumed surface reflectance since the latter changes slowly with time over the warm season, when successful measurements occur more frequently. A MODIS algorithm designed to function over inhomogeneous surfaces such as the AOSR region, and which would also likely be applicable to urban areas, is being investigated to exploit the many benefits of MODIS radiance data. One such benefit is the twice-daily revisit over the AOSR that the current multi-angle sensors, namely MISR and SLSTR (Sea and Land Surface Temperature Radiometer) (Coppo et al., 2010), cannot offer. SLSTR, on board the recently launched Sentinel-3a satellite, is the next generation in the ATSR series.

MISR clearly captures the short-term and month-to-month AOD variability at Fort McMurray based on correlations at the individual coincidence level and the monthly timescale (Table 4) but struggles to capture the local spatial variability including the AOD hotspot in the AOSR as discussed in Sect. 3. The MISR low bias may be related to the need for darker spherical particles (Kahn et al., 2010) given that forest fire smoke plays a significant role throughout western Canada in the warm season (O'Neill et al., 2002). Spherical particles with lower single-scattering albedo (SSA) may also be required to properly represent local anthropogenic pollution (Kahn et al., 2010) in the AOSR. The $3 \times 3$ superpixel averaging that is used when the MISR retrieval fails for the central superpixel could also contribute to a low bias (Jiang et al., 2007), particularly at Fort McKay as background AODs to the west could be lowering the average.

AATSR has a major spatial sampling issue in the heart of the AOSR but also captures month-to-month variability from late spring to early autumn (Table 4) as well as short-term (Table 4) and spatial variability (Table 3 ). Based on a previous analysis (Che et al., 2016), the AATSR AOD underestimation of the Swansea University product (also used here) is larger over barren surfaces or sparse vegetation. Such land cover types are present in the AOSR.

POLDER has a known negative offset in AOD (Deuzé et al., 2001), confirmed using coincident Fort McMurray AERONET AOD data. For the temporal trend calculation, the approach of using relative anomalies based on bias-corrected AODs is particularly important for 
POLDER/PARASOL because the very low $865 \mathrm{~nm}$ AODs (Fig. 1) and the negative offset (Table 4) do not allow a relative trend to be meaningful without bias correction. Nevertheless, POLDER/PARASOL is among the most accurate satellite-based aerosol sensors at Fort McMurray during periods of higher AODs (e.g. $\geq 0.4$, Table 4), when its negative offset becomes rather trivial. Overall, the POLDER AOD product is without a major weakness relative to the other instruments, although it is provided at a relatively coarse spatial resolution (Table 1), and the fixed spatial sampling pattern of this sensor inhibits the application of spatial oversampling techniques. The use of polarized radiances reduces the sensitivity of the retrieved AOD to surface reflectance (e.g. Deuzé et al., 2001). The trend in POLDER/PARASOL AOD at the Shell mines (Albian and Shell Muskeg River) is probably not driven by a trend in surface reflectance since agreement with AERONET tends to be independent of surface type (e.g. Chen et al., 2015). A future sensor of POLDER heritage - namely the Multi-viewing, Multi-channel, Multipolarization Imager (3MI) - offers higher spatial resolution, the availability of longer wavelength channels, and the potential for accurate monitoring of the local aerosol loading in the decade to come.

While AODs in the AOSR are relatively small according to POLDER/PARASOL (Fig. 1), the significantly positive trend in AOD from this satellite sensor and the similar trend in observed surface-level $\mathrm{PM}_{2.5}$ in the region of the Muskeg River mine point to the need to continue monitoring of this region with a combination of surface and satellite-based aerosol observations.

\section{Data availability}

MODIS data are obtained from ftp://ladsweb.nascom.nasa. gov/allData/. AATSR and ATSR-2 version 4.1 data are from Swansea University and can be obtained from the Aerosol Climate Change Initiative (CCI) website (http:// www.esa-aerosol-cci.org/) following registration. The current file version (F12) is used for MISR (ftp://15eil01.larc. nasa.gov/MISR/MIL2ASAE.002). POLDER data were obtained from CNES (http://polder.cnes.fr), but data can currently be obtained from http://www.icare.univ-lille1.fr/ following registration. 


\section{Appendix A: Data product notes}

The selected MISR AOD product is named the "regional best estimate of spectral 10 optical depth". A POLDER AOD datum is filtered if any of the following statements are true (see Bréon, 2011):

1. The central pixel is snow-covered.

2. One of the cloud tests is not applied.

3. None of the nine radiance pixels which form the AOD superpixel has clear sky.

4. Sufficient data couples do not exist. The couples are

- 865 and $910 \mathrm{~nm}$,

- Q443 and U443,

- Q670 and U670,

- Q865 and U865,

where $\mathrm{Q}$ and $\mathrm{U}$ are the derived Stokes elements and the number is the wavelength (in $\mathrm{nm}$ ) of the channel.

5. Ozone absorption is not corrected (using TOMS or ECMWF).

6. Stratospheric aerosol correction is uncertain or imprecise (i.e. stratospheric AOD larger than a certain threshold).

7. Minimum scattering angle is larger than a threshold, or maximum scattering angle is smaller than a threshold.

8. Aerosol optical thickness is larger than a threshold such that surface reflectance cannot be estimated adequately.

9. A large difference between measured and modelled reflectance exists for $443 \mathrm{~nm}$.

10. Differences are too large between measured and modelled reflectance (risk of glitter).

11. Meteorological data indicate the presence of snow at ground level.

12. The quality index is 0.00 for viewing geometry conditions.

13. The quality index is 0.00 for polarized reflectance fit. 
Competing interests. The authors declare that they have no conflict of interest.

Acknowledgements. Helpful discussions with Shailesh Kharol (ECCC) on the size range of dust particles are gratefully acknowledged. The European Space Agency Climate Change Initiative program is acknowledged. Peter North (Swansea University) is thanked for comments on an earlier version of the manuscript.

Edited by: J. Liggio

Reviewed by: two anonymous referees

\section{References}

Bari, M. and Kindzierski, W. B.: Fifteen-year trends in criteria air pollutants in oil sands communities of Alberta, Canada, Environ. Int., 74, 200-208, 2015.

Bari, M. A. and Kindzierski, W. B.: Evaluation of air quality indicators in Alberta, Canada - An international perspective, Environ. Int., 92-93, 119-129, 2016.

Bergström, P. and Edlund, O.: Robust registration of point sets using iteratively reweighted least squares, Comput. Optim. Appl., 58, 543-561, 2014.

Bevan, S. L., North, P. R. J., Los, S. O., and Grey, W. M. F.: A global dataset of atmospheric aerosol optical depth and surface reflectance from AATSR, Remote Sens. Environ., 116, 199-210, 2012.

Bilal, M., Nichol, J. E., and Nazeer, M.: Validation of Aqua-MODIS C051 and C006 operational aerosol products using AERONET measurements over Pakistan, IEEE J. Selected Topics Appl. Earth Observations Remote Sens., 9, 2074-2080, 2016.

Bréon, F. M.: Parasol Level-2 product data format and user manual, Ed. 1 - Rev. 6, 2011.

Carroll, M. L., DiMiceli, C. M., Townshend, J. R. G., Sohlberg, R. A., Elders, A. I., Devadiga, S., Sayer, A. M., and Levy, R. C.: Development of an operational land water mask for MODIS Collection 6, and influence on downstream data products, Int. J. Digital Earth, 10, 207-218, doi:10.1080/17538947.2016.1232756, 2017.

Che, Y., Xue, Y., Mei, L., Guang, J., She, L., Guo, J., Hu, Y., Xu, H., He, X., Di, A., and Fan, C.: Technical note: Intercomparison of three AATSR Level 2 (L2) AOD products over China, Atmos. Chem. Phys., 16, 9655-9674, doi:10.5194/acp-16-96552016, 2016.

Chen, H., Cheng, T., Gu, X., Li, Z., and Wu, Y.: Evaluation of polarized remote sensing of aerosol optical thickness retrieval over China, Remote Sens., 7, 13711-13728, doi:10.3390/rs71013711, 2015.

Coppo, P., Ricciarelli, B., Brandani, F., Delderfield, J., Ferlet, M., Mutlow, C., Munro, G., Nightingale, T., Smith, D., Bianchi, S., Nicol, P., Kirschstein, S., Hennig, T., Engel, W., Frerick, J., and Nieke, J.: SLSTR: a high accuracy dual scan temperature radiometer for sea and land surface monitoring from space, J. Modern Opt., 57, 1815-1830, doi:10.1080/09500340.2010.503010, 2010.

Demerjian, K. L.: A review of national monitoring networks in North America, Atmos. Environ., 34, 1861-1884, 2000.
Deschamps, P.-Y., Bréon, F.-M., Leroy, M., Podaire, A., Bricaud, A., Buriez, J.-C., and Sèze, G.: The POLDER mission: Instrument characteristics and scientific objectives, IEEE Trans. Geosci. Remote Sens., 32, 598-615, 1994.

Deuzé, J. L., Bréon, F. M., Devaux, C., Goloub, P., Herman, M., Lafrance, B., Maignan, F., Marchand, A., Nadal, F., Perry, G., and Tanré, D.: Remote sensing of aerosols over land surfaces from POLDER-ADEOS-1 polarized measurements, J. Geophys. Res., 106, 4913-4926, 2001.

Diner, D. J., Bruegge, C. J., Martonchik, J. V., Ackerman, T. P., Davies, R., Gerstl, S. A. W., Gordon, H. R., Sellers, P. J., Clark, J., Daniels, J. A., Danielson, E. D., Duval, V. G., Klassen, K. P., Lilienthal, G. W., Nakamoto, D. I., Pagano, R., and Reilly, T. H.: MISR: A Multi-angle Imaging SpectroRadiometer for geophysical and climatological research from Eos, IEEE T. Geosci. Remote Sens., 27, 200-214, 1989.

Diner, D. J., Abdou, W. A., Ackerman, T. P., Crean, K., Gordon, H. R., Kahn, R. A., Martonchik, J. V., McMuldroch, S., Paradise, S. R., Pinty, B., Verstraete, M. M., Wang, M., and West, R. A.: Multi-angle Imaging SpectroRadiometer Level 2 aerosol retrieval algorithm theoretical basis, Revision G, JPL D-11400, Jet Propulsion Laboratory, California Institute of Technology, 2008.

Foote, L.: Threshold considerations and wetland reclamation in Alberta's mineable oil sands, Ecol. Soc., 17, 35, 2012.

Hillger, D., Kopp, T., Lee, T., Lindsey, D., Seaman, C., Miller, S., Solbrig, J., Kidder, S., Bachmeier, S., Jasmin, T., and Rink, T.: First-light imagery from Suomi NPP VIIRS, B. Am. Meteorol. Soc., 94, 1019-1029, 2013.

Holben, B., Eck, T., Slutsker, I., Tanre, D., Buis, J. P., Setzer, A., Vermote, E., Reagan, J. A., Kaufman, Y. J., Nakajima, T., Lavenu, F., Jankowiak, I., and Smirnov, A.: AERONET - A federated instrument network and data archive for aerosol characterization, Remote Sens. Environ., 66, 1-16, 1998.

Hsu, N. C., Jeong, M.-J., Bettenhausen, C., Sayer, A. M., Hansell, R., Seftor, C. S., Huang, J., and Tsay, S.-C.: Enhanced Deep Blue aerosol retrieval algorithm: The second generation, J. Geophys. Res.-Atmos., 118, 9296-9315, doi:10.1002/jgrd.50712, 2013.

Hsu, Y.-M., Wang, X., Chow, J. C., Watson, J. G., and Percy, K. E.: Collocated comparisons of continuous and filter-based $\mathrm{PM}_{2.5}$ measurements at Fort McMurray, Alberta, Canada, J. Air Waste Manage., 66, 329-339, 2016.

Hubanks, P.: MODIS atmosphere QA plan for Collection 006, Greenbelt, MD, USA, NASA Goddard Space Flight Center, version 8, 2015.

Jiang, X., Liu, Y., Yu, B., and Jiang, M.: Comparison of MISR aerosol optical thickness with AERONET measurements in Beijing metropolitan area, Remote Sens. Environ., 107, 45-53, 2007.

Kahn, R. A., Gaitley, B. J., Martonchik, J. V., Diner, D. J., Crean, K. A., and Holben, B.: Multiangle Imaging Spectroradiometer (MISR) global aerosol optical depth validation based on 2 years of coincident Aerosol Robotic Network (AERONET) observations, J. Geophys. Res., 110, D10S04, doi:10.1029/2004JD004706, 2005.

Kahn, R. A., Gaitley, B. J., Garay, M. J., Diner, D. J., Eck, T. F., Smirnov, A., and Holben, B. N.: Multiangle Imaging SpectroRadiometer global aerosol product assessment by comparison with the Aerosol Robotic Network, J. Geophys. Res., 115, D23209, doi:10.1029/2010JD014601, 2010. 
Kaufman, Y. J., Tanré, D., and Boucher, O.: A satellite view of aerosols in the climate system, Nature, 419, 215-223, 2002.

Kelly, F. J., Fuller, G. W., Walton, H. A., and Fussel, J. C.: Monitoring air pollution: Use of early warning systems for public health, Respirology, 17, 7-19, 2012.

Levy, R. C., Mattoo, S., Munchak, L. A., Remer, L. A., Sayer, A. M., Patadia, F., and Hsu, N. C.: The Collection 6 MODIS aerosol products over land and ocean, Atmos. Meas. Tech., 6, 29893034, doi:10.5194/amt-6-2989-2013, 2013.

Levy, R. C., Munchak, L. A., Mattoo, S., Patadia, F., Remer, L. A., and Holz, R. E.: Towards a long-term global aerosol optical depth record: applying a consistent aerosol retrieval algorithm to MODIS and VIIRS-observed reflectance, Atmos. Meas. Tech., 8, 4083-4110, doi:10.5194/amt-8-4083-2015, 2015.

Li, C., Hsu, N. C., Sayer, A. M., Krotkov, N. A., Fu, J. S., Lamsal, L. N., Lee, J., and Tsay, S.-C.: Satellite observation of pollutant emissions from gas flaring activities near the Arctic, Atmos. Environ., 133, 1-11, 2016.

Li, R.-R., Remer, L., Kaufman, Y. J., Mattoo, S., Gao, B.-C., and Vermote, E.: Snow and ice mask for the MODIS aerosol products, IEEE Geosci. Remote Sens. Lett., 2, 306-310, 2005.

Li, Z., Zhao, X., Kahn, R., Mishchenko, M., Remer, L., Lee, K.-H., Wang, M., Laszlo, I., Nakajima, T., and Maring, H.: Uncertainties in satellite remote sensing of aerosols and impact on monitoring its long-term trend: a review and perspective, Ann. Geophys., 27, 2755-2770, doi:10.5194/angeo-27-2755-2009, 2009.

Liggio, J., Li, S.-M., Hayden, K., Taha, Y. M., Stroud, C., Darlington, A., Drollette, B. D., Gordon, M., Lee, P., Liu, P., Leithead, A., Moussa, S. G., Wang, D., O’Brien, J., Mittermeier, R. L., Brook, J., Lu, G., Staebler, R., Han, Y., Tokarek, T. T., Osthoff, H. D., Makar, P. A., Zhang, J., Plata, D., Gentner, D. R.: Oil sands operations are a major source of secondary organic aerosols, Nature, 534, 91-94, 2016.

Liu, Y., Sarnat, J. A., Coull, B. A., Koutrakis, P., and Jacob, D. J.: Validation of Multiangle Imaging Spectroradiometer (MISR) aerosol optical thickness measurements using Aerosol Robotic Network (AERONET) observations over the contiguous United States, J. Geophys. Res., 109, D06205, doi:10.1029/2003JD003981, 2004.

Loría-Salazar, S. M., Holmes, H. A., Arnott, W. P., Barnard, J. C., Moosmüller, H.: Evaluation of MODIS columnar aerosol retrievals using AERONET in semi-arid Nevada and California, U.S.A., during the summer of 2012, Atmos. Environ., 144, 345360, 2016.

Lyapustin, A., Wang, Y., Laszlo, I., Kahn, R., Korkin, S., Remer, L., Levy, R., and Reid, J. S.: Multiangle implementation of atmospheric correction (MAIAC): 2. Aerosol algorithm, J. Geophys. Res., 116, D03211, doi:10.1029/2010JD014986, 2011.

McLinden, C. A., Fioletov, V., Boersma, K. F., Krotov, N., Sioris, C. E., Veefkind, P., and Yang, K.: Air quality over the Canadian oil sands: A first assessment using satellite observations, Geophys. Res. Lett., 39, L04804, doi:10.1029/2011GL050273, 2012.
McLinden, C. A., Fioletov, V., Krotkov, N., Li, C., Boersma, K. F., and Adams, C.: A decade of change in $\mathrm{NO}_{2}$ and $\mathrm{SO}_{2}$ over the Canadian oil sands as seen from space, Environ. Sci. Technol., 50, 331-337, doi:10.1021/acs.est.5b04985, 2016.

Myhre, G., Shindell, D., Bréon, F.-M., Collins, W., Fuglestvedt, J., Huang, J., Koch, D., Lamarque, J.-F., Lee, D., Mendoza, B., Nakajima, T., Robock, A., Stephens, G., Takemura, T., and Zhang, H.: Anthropogenic and Natural Radiative Forcing, in: Climate Change 2013: The Physical Science Basis. Contribution of Working Group I to the Fifth Assessment Report of the Intergovernmental Panel on Climate Change, edited by: Stocker, T. F., Qin, D., Plattner, G.-K., Tignor, M., Allen, S. K., Boschung, J., Nauels, A., Xia, Y., Bex, V., and Midgley, P. M., Cambridge University Press, Cambridge, United Kingdom and New York, NY, USA, 2013.

O’Neill, N. T., Eck, T. F., Holben, B. N., Smirnov, A., Royer, A., and Li, Z.: Optical properties of boreal forest fire smoke derived from Sun photometry, J. Geophys. Res., 107, 4125, doi:10.1029/2001JD000877, 2002.

Popp, T., de Leeuw, G., Bingen, C., Brühl, C., Capelle, V., Chedin, A., Clarisse, L., Dubovik, O., Grainger, R., Griesfeller, J., Heckel, A., Kinne, S., Klüser, L., Kosmale, M., Kolmonen, P., Lelli, L., Litvinov, P., Mei, L., North, P., Pinnock, S., Povey, A., Robert, C., Schulz, M., Sogacheva, L., Stebel, K., Zweers, D. S., Thomas, G., Tilstra, S., Vandenbussche, L. G., Veefkind, P., Vountas, M., and Xue, Y.: Development, production and evaluation of aerosol Climate Data Records from European satellite observations (Aerosol_cci), Remote Sensing, 8, 421, doi:10.3390/rs8050421, 2016.

Sayer, A. M., Hsu, N. C., Bettenhausen, C., and Jeong, M.-J.: Validation and uncertainty estimates for MODIS Collection 6 "Deep Blue" aerosol data, J. Geophys. Res.-Atmos., 118, 7864-7872, doi:10.1002/jgrd.50600, 2013.

Stieb, D. M., Burnett, R. T., Smith-Doiron, M., Brion, O., Shin, H. H., and Economou, V.: A New Multipollutant, No-Threshold Air Quality Health Index Based on Short-Term Associations Observed in Daily Time-Series Analyses, J. Air Waste Manage., 58, 435-450, 2008.

Tian, J. and Chen, D.: Spectral, spatial, and temporal sensitivity of correlating MODIS aerosol optical depth with ground-based fine particulate matter $\left(\mathrm{PM}_{2.5}\right)$ across southern Ontario, Can. J. Remote Sens., 36, 119-128, 2010.

van Donkelaar, A., Martin, R. V., Brauer, M., Hsu, N. C., Kahn, R. A., Levy, R. C., Lyapustin, A., Sayer, A. M., and Winker, D. M.: Global estimates of fine particulate matter using a combined geophysical-statistical method with information from satellites, models, and monitors, Environ. Sci. Technol., 50, 3762-3772, 2016.

Wu, A., Xiong, X., Doelling, D. R., Morstad, D., Angal, A., and Bhatt, R.: Characterization of Terra and Aqua MODIS VIS, NIR, and SWIR spectral bands' calibration stability, IEEE T. Geosci. Remote Sens., 51, 4330-4338, 2013. 